\title{
How demographic patterns and social policies shape interdependence among lives in the family realm
}

\author{
Pearl A. Dykstra ${ }^{1 \star}$, Gunhild O. Hagestad ${ }^{2}$
}

\begin{abstract}
Our starting point is that a social psychological approach dominates the literature on interdependent or "linked" lives (Elder, 1994). We argue that interdependence is not only social-psychological, but is also structured on a macro-level. More specifically, we illustrate ways in which demographic change, such as increased co-longevity, creates different opportunities for interdependence for men and women. In addition, we draw attention to the role of national policies, distinguishing ways in which legislation mandates generational interdependence (e.g., legal obligations to provide financial support), blocks generational interdependence (e.g., grandparents not granted the right to raise grandchildren when parents cannot provide adequate care; migration laws not granting temporary visits to enable the provision of care), generates generational interdependence (e.g., daddy quota), and lightens generational interdependence (e.g., less reliance on grandparental care in Northern and Western Europe due to public support to parents of young children). We pay specific attention to childless men and women, questioning the primacy assigned to kinship ties in health care and long-term support policies. Gender receives consistent consideration throughout the paper.
\end{abstract}

Keywords: life course, interdependence, linked lives, policies, demographic change, gender

\section{Background and theoretical starting point}

As social science colleagues, the authors share a strong interest in issues and concepts introduced in the life course perspective (Hagestad \& Dykstra, 2016). A key concept and "organizing principle" in this perspective is that lives are interdependent: linked and interwoven. We agree with Marshall and Bengtson (2011) who state that "the concept of 'linked lives' has proven the most useful tool in understanding the actions and interactions of family members over time" (p. 25). In his classic volume on Children of the Great Depression, Elder (1974) shows how transitions of one family member affect the life chances of others. He also shows how the family realm is a critical mediating force between societal changes and the micro-level of individual lives.

Four decades later, Elder, Shanahan, and Jennings (2015) sum up: "lives are lived interdependently and social-historical influences are expressed through this network of shared relationships. [...] Interdependent

Article note: This article draws upon and elaborates earlier work of Hagestad and Dykstra published in the Handbook of the Life Course, Volume II (2016).

\footnotetext{
`Corresponding author: dykstra@fsw.eur.nl 1Department of Public Administration and Sociology, Erasmus University Rotterdam. Financial support for this author comes from the European Research Council Advanced Investigator Grant (ERC, 324211) "Families in Context”, and from the European Union Seventh Framework Large Scale Integrating Project (EC, 320116) “FamiliesAndSocieties”.

${ }^{2}$ Centre for Welfare and Labour Research, Oslo and Akershus University College of Applied Sciences
} 
lives highlight the role of significant othersin regulating and shaping the timing of life trajectories through a network of informal control [...] the expectations and informal sanctions of these 'others' channel behavior and the life course in certain directions” (p. 31). Thus, within this perspective, a web of interconnected lives serves as a "developmental context" for persons throughout life. In the family realm, individual life chances, opportunities and constraints are shaped by key consociates. Transitions of one member affect trajectories of close others. In some cases, individuals go through countertransitions: life changes resulting from transitions made by central others (Hagestad, 1991). Examples are becoming a grandparent or an in-law.

Several authors have pointed out that most North American work inspired by Elder's framework takes a social psychological approach, and that US and European scholars have tended to focus on different levels of social context in discussions of how life trajectories are shaped. An example is Leisering (2004), who suggests that US researchers have tended to emphasize the micro and meso levels of individuals and their families, contemplating culture and shared meaning as the main organizing force in shaping lives, whereas European researchers of the life course have focused more strongly on the structuring influences of the state (see Mayer \& Müller, 1986, for a classic example of the latter). Interdependence not only entails informal social control, but is also shaped on a societal level, through formal laws and regulations.

In a similar vein, we also argue that demographic conditions in a population shape conditions for interdependence between lives by affecting the size and composition of family networks and the duration of ties for men and women.

To illustrate how life transitions and trajectories are influenced by macro-level structural dynamics, we focus on how interdependence in vertical, crossgenerational family ties is influenced by two sets of societal forces: demographic conditions and national social policy. Both these macro-level phenomena shape matrices of contingencies and interdependencies across individual lives. Our aim in this discussion is twofold. First, we provide illustrations of the ways in which demographic patterns such as lowered fertility, reduced and more predictable mortality, and increased co-longevity create new conditions of generational interdependence for men and women. Second, we focus on the role of national policies, illustrating ways in which legislation shapes family relations by mandating, blocking, generating, or lightening generational interdependence. Throughout our discussion, we consider gender contrasts in how patterns of interdependence are structured on a macro level. We also give examples of variability across societies and explore life course challenges of statistical outliers and their significance for families and social services.

\section{Interdependence and patterns of demographic change}

A number of authors have recently emphasized the complex ways in which altered mortality and fertility patterns not only change the population pyramid into an onion or column, and eventually might create an inverted pyramid, but also change the generational structures of families and life course patterns within them (Bengtson, 2001; Gee, 1987; Leopold \& Skopek, 2015; Murphy, 2011, Uhlenberg, 2004, 2009). Verdery (2015) concludes that "the demographic transition is also a kinship transition” (p. 466). Uhlenberg (1996) writes about "mutual attraction" between demography and life course analysis. He presents a powerful example of historical change: US 20-year-olds in the year 2000 were more likely to have a grandmother still living (91\%) than 20-year-olds in 1900 were to have a mother living (83\%). All these authors build on earlier ground-breaking work, such as Glick's writing on the family life cycle, published in the 1940s and 50s (e.g., Glick, 1947) and Ryder's (1965) discussion of cohorts and social change.

The demographic transition has altered the balance between young and old in the population, as well as the statistical balance between men and women, especially in later life. Given gender differences in life expectancies, societal aging entails a "feminization" of older populations. The new patterns also alter durations of role engagements in two central family relationships: parent-child and grandparent-grandchild. These changes entail clearer gender contrasts.

For most of human history, children have constituted at least half of the population, the old only a small percentage. Today, Africa is the only continent where this demographic picture still can be found. According to current figures (Population Reference Bureau, 2015) the overall picture is that children 15 and younger constitute $41 \%$ of the population; $4 \%$ are 65 and older. Niger is the "youngest" society, with a 
population that counts more than $50 \%$ children. The population of Asia as a whole has $25 \%$ children and $8 \%$ old people, but in the world's "oldest" society, Japan, there are twice as many old as young (26\% versus $13 \%)$. Europe has an even balance between old and young ( $17 \%$ versus $16 \%)$. Canada and the US resemble Europe. In Canada, the figure for both young and old is $16 \%$, while the neighboring nation has $19 \%$ young; $15 \%$ old. The figures for median ages reflect the patterns just described (United Nations, 2015): Africa 19, Asia 30, Europe 42, and North America 38. Among nations with the highest median ages in the world, Japan tops the list (47). In Europe, Italy has the highest figure (46).

Closely related to the demographic transition is the epidemiological transition: a shift from mortality linked to infectious disease to "wear and tear", lifestyle-related illness as causes of death. Often this shift is seen as the basis of increasing gender differences in life expectancy (Wheaton \& Crimmins, 2016). Recent figures (Population Reference Bureau, 2015) show that in more developed countries, the average difference between men and women in life expectancy at birth is 6 years. The figure for Europe is 7 years; in the US, 5 years. Looking across Europe, the smallest gender difference is in Iceland, where women can expect to live 3 years longer than men. In sharp contrast, six countries in Eastern and Central Europe have a difference of 10 years or more. Belarus, Lithuania and Russia show a gap of 11 years. Differences are considerably smaller in Africa and certain parts of Asia. According to most recent figures, Swaziland is the only nation in the world with a higher life expectancy for men than for women, while Mali has the same figure for men and women. Gender differences in mortality and morbidity patterns create imbalanced sex ratios, especially among the oldest old. While Africa has an overall ratio of 68 men per 100 women among individuals 80 and older, the corresponding figure for Europe is 50; for North America, 60.

\section{Parents and children}

Several scholars have taken a historical view of the proportion of adult life spent in two key roles-that of parent and that of child. Gee (1987) reminds us that for the first time in human history, individuals now spend more years as adult children with surviving parents than they do as parents of minor children. She estimates that under 1860 conditions, $16 \%$ of Canadian 50-year olds had living parents, compared to $60 \%$ a hundred years later. In aging populations, it is common for mature men and women to still occupy the role of child, but the parent is typically the mother. In the Norwegian NorLAG/LOGG study, almost 9 out of 10 respondents aged 50 and older who have at least one parent still living, have mothers; only around one third have fathers (Herlofson \& Hagestad, 2011). Among respondents 60 and older, having a surviving parent means almost exclusively having mothers (92\% versus 17\%) (ibid.). Herlofson and Hagestad (2011) point out that as a consequence, many more mothers and daughters compared to fathers and sons share the experience of growing old together, a fact that is often overlooked in research on intergenerational relations.

Analyses of panel data (ibid.) from the two waves in NorLAG/LOGG (data collections in 2002/2003 and 2007/2008) showed that among old parents who needed help during both surveys-according to their adult children-84\% were mothers. It is also important to bear in mind that while the majority of old men live with a partner, most old women live alone. The same authors report Norwegian statistics showing 59\% of men over 80 are married, compared to only $19 \%$ of women (Hagestad and Herlofson 2010). As a consequence, old men can often call upon their partner for care; older women look to younger generations (ibid.).

\section{The bookend generations: Ties between young and old}

Demographic conditions for interdependence between old and young vary strongly across societies. In 2005, there were 81 women aged 65 and older per 100 children under 15 in Italy. The corresponding figure for old men was 57 per 100 children. In stark contrast, the figures for the Russian Federation were 62 women and 29 men per 100 children. Both on a societal level and in families, it is reasonable to conclude that Russian children grow up having highly limited contact with old men. Overall, because of changes in life expectancy, a predominant pattern is that women's cross-generational ties are characterized by "co-longevity" and long durations. This fact has received little attention in the life course literature, and in writing on age and gender.

Reduced fertility has led to clearer sequencing between active parenting and grandparenting and less "competition" between the parent and grandparent roles (Leopold \& Skopek, 2015). Uhlenberg (2009) points to one more fertility-related factor affecting 
contact and closeness between grandparents and grandchildren: fewer children in the middle generation means a reduced number of grandchild sets. It is hardly an exaggeration to say that we have seen a revolution in grandparenthood, a change that reflects the main drivers of the demographic transition.

Children's kin networks have been more affected by population ageing than is the case for the old. For example, it is reasonable to assume that there were just as many grandparents among individuals who survived to old age a century ago as is the case today. In sharp contrast, children today are about seven to eight times more likely to have all four grandparents living than was the case in 1900 (Hagestad \& Uhlenberg, 2007; Uhlenberg, 1996). According to Uhlenberg's (1996) estimates, $5 \%$ of 10-year-olds in the US at the start of the 1900s had four grandparents; by 2005, the figure was $40 \%$. This last figure is very similar to what emerged from the 2005 Norwegian grandparenthood study, a survey anchored in children aged 10-12: $41 \%$ had all four (Hagestad, 2006). Micro-simulation models reveal an increase in the proportion of 0-20 year-olds with four surviving grandparents in the Netherlands from 10\% in 1950 to 20\% in 1990 (Post, Van Imhoff, Dykstra \& Van Poppel, 1997). Thus, the availability of grandparents is not limited to childhood. Estimates for the US (Uhlenberg, 1996) show that the proportion of 30 year-olds with at least one grandparent alive more than tripled between 1900 and 2000 , from $21 \%$ to $75 \%$. The expectation for 2020 is a further increase to $80 \%$.

Clearly, population ageing has created unprecedented webs of interdependent ties across family generations. Taking a multigenerational view of family bonds, we now turn to a discussion of the ways in which national laws and policies shape interdependence among young and old in families.

\section{Interdependence: the impact of laws and policies}

Countries differ greatly in their understanding of "proper" cross-generational family relations (Viazzo, 2010), and the ways in which their state mechanisms influence linked lives. Policies and laws create, assume, reinforce, block and lighten connections between the lives of parents, children, grandparents, and grandchildren. A number of scholars have developed models of "care regimes", focusing on publicly funded care policies for the young and the old (e.g., Anttonen \& Sipilä, 1996; Bettio \& Plantenga, 2004; Leitner, 2003; Saraceno \& Keck, 2010; Zagel \& Lohmann, 2016). An attractive feature of these models is that they overcome a "chopped up" view of families by considering multiple generations. A key distinction in this literature is the extent to which welfare states impose reliance on family members ("familialisation") or enable individual autonomy ("defamilialisation").

As Leisering (2004) notes, policies can have a direct or an indirect influence on people's lives. The influence is direct when there are clear sanctions to non-adherence. For example, parents who do not provide for their children's safety and well-being are subjected to interference by state authorities. The influence of policies is indirect when the state modifies opportunity structures (and the incentive structures), for example through the introduction of cash benefits.

We discuss four ways in which national legislation shapes cross-generational interdependence in families, focusing mostly on Europe. Our inspiration comes from the concepts of familialisation and defamilialisation, and we distinguish whether the influence of laws and policies on people's lives is direct or indirect. A novelty of our categorization is that we also consider legislation that blocks generational interdependence.

\section{Legislation shaping cross-generational interdependence}

All nations have mandated interdependence, policies that directly interfere in people's lives by imposing obligations to obey or provide for given family members (familialism). Examples are maintenance responsibilities, and a power of attorney to act on behalf of an older person deemed legally unfit to make independent decisions. All European countries have regulations obliging parents to financially support their children, but they vary in terms of the age of the child up until which this obligation is imposed. Europe shows strong cross-county variation regarding the legal obligations of adult offspring to financially support parents. The countries that legally oblige children to provide for their parents tend to be in Southern, Central and Eastern Europe. For details on legal family obligations, see Saraceno and Keck (2008), and the Multilinks database (2011).

National legislation can also block interdependence, directly interfering in people's lives by disabling the maintenance of unions with family members. Examples are grandparents who are not 
granted the right to raise grandchildren when parents cannot provide adequate care, or parents who have court orders prohibiting them from having contact with their children after divorce. Immigration and refugee policies, which determine who gets to come and who gets to stay, are another example (Saraceno, forthcoming). A highly restrictive definition of family ties (normally limited to spouses and dependent children), and strict requirements, such as stable income of the sponsor and adequate housing, keep grandparents in migrant families separated from their grandchildren, and adult children in migrant families separated from their ageing parents. Families do not necessarily become transnational because they decide that this is an optimal arrangement, but rather because immigration policies restrict family members from joining one another in the receiving country (Carling, Menjivar, \& Schmalzbauer, 2012: Zhou 2012).

A third way in which national laws and policies shape the ways in which family lives are connected is by aiming to generate cross-generational interdependence. The incentive structure is changed in such a way that citizens feel motivated to adopt new roles, and more specifically, to become more familialistic. The so-called "daddy quota" is an example (Eydal \& Rostgaard, 2015). This is a nontransferable, use-it-or-lose-it share of parental leave reserved for fathers. Such legislation was introduced to improve citizens' work-life balance, foster gender equality, enable men to spend more time with their offspring, and improve the educational outcomes of children. There is mounting evidence that men who have taken up paid parental leave (a) have fewer conflicts over the division of household tasks and are more likely to share them (e.g., Kotsadam \& Finseraas, 2011), (b) are more involved in childcare and childrearing- particularly highly educated fathers (e.g., Boll, Leppin, \& Reich, 2014), but (c) are not more involved in caring for frail parents (e.g., Herlofson \& Ugreninov, 2014). Given the proven success of the daddy quota, The Economist (2016) has now added paid paternity leave to its "glass-ceiling index", which ranks countries by how good it is to be a working woman in each of them. It is published yearly to mark International Women's Day.

Finally, state mechanisms can lighten family interdependence. Research on grandparental care (Bordone, Arpino, \& Aassve, 2016) provides a powerful example of policies that enable autonomy in families (defamilialisation). In Europe, the likelihood that grandparents provide childcare on a daily basis is strongly linked to the availability of public policy arrangements. In countries where childcare services and parental leaves are most generous, grandparents are least likely to provide daily care to grandchildren while daughters and daughtersin-law are at work. Grandparents are not compelled to step in-because there are public arrangements facilitating the combination of paid work and parenting responsibilities. Another example of the way in which state arrangements lighten crossgenerational interdependence in families comes from research on support to ageing parents. Studies have repeatedly shown that when paid professionals take on complex, repetitive and intensive care tasks, adult children have more time to provide unstructured and non-technical help (e.g., Bonsang, 2009; Brandt, Haberkern, \& Szydlik, 2009). Adults aged 50 and over are more likely to provide practical help (i.e. household help, transportation, odd jobs around the house, filling in forms) to ageing parents in European countries where higher proportions of the work force are engaged in the health and social sector, such as the Netherlands, Denmark, and Sweden. Conversely, adults aged 50 and over are more likely to provide care (i.e. assistance with getting dressed, bathing, feeding, getting in and out of bed) to ageing parents in European countries where lower proportions of the work force are engaged in the health and social sector (e.g., Greece, Italy and Spain).

\section{Public provisions and gender inequality}

Feminist scholars have pointed to the gendered consequences of welfare state provisions (e.g., O'Connor, 1996; Orloff, 1993). A telling example is the differential retirement age for men and women. In 2012, 19 of 39 OECD and EU countries had lower statutory retirement ages for women than men, but this number is dropping (European Commission, 2015; OECD, 2015). One of the reasons put forward for having an earlier retirement age for women is to compensate for the "double shift" many of them experience: combining housework, family care and a paid job (Brocas, Cailloux, \& Oget, 1990). In practice, however, women's career breaks and early exit from the labour market impact adversely on the adequacy of their pensions (European Commission, 2015).

Regarding government measures aimed at the conciliation of paid work and caregiving tasks, an important issue is whether policies involve payments 
for care or the provision of care services (Javornik, 2014; Lohmann \& Zagel, 2016; Saraceno, 2010). When public support is offered in money rather than in kind, trade-offs between (a) using it to buy services or (b) keeping it for the family budget and staying at home to provide care, might be different for families in different socioeconomic circumstances. The latter strategy might more readily be adopted by members of the working-class, reducing their ability to remain in gainful employment and contributing to the likelihood of old-age poverty for themselves. In practice, women with limited occupational histories and labour market prospects will be providing the care.

Empirical evidence that types of public provision have consequences for gender inequality is now emerging. For example, Abendroth, Huffman and Treas (2014) demonstrate that the motherhood occupational status penalty is lower in European countries where expenditures on public childcare are higher. Confirming earlier findings, Schmid, Brandt and Haberkern (2012) show that women are more likely to provide intensive care to aging parents than men are. However, the gender gap in the provision of such care is greater when aging parents receive cash for care payments (in addition to the care received from adult children) than when they receive services in kind. Apparently, the public provision of support services helps to keep both men and women involved in caring for frail parents, whereas care payments are a greater incentive for women than for men.

\section{Public provisions and the childless}

The primacy of spouses, parents and children as "selfevident" sources of support is strongly reflected in health care and long-term support policies, thereby neglecting the lives of individuals with no or highly limited vertical family ties, such as the childless (Ivanova \& Dykstra, 2015). Benefits available to family caregivers are not available to friends who have taken on caregiving roles usually assumed by close kin. In all of the 38 countries covered in Moss's (2015) review of leave policies, the person who can take leave is a family member (usually a child or a spouse), and never a friend. ${ }^{1}$ Non-kin often lack the legal

1 We note, however, that in the Netherlands as of July 1st 2015, employees who are unable to work because they need to take care of a severely sick housemate, friend or neighbour will be able to request care leave from their employer. Previously, employees were only eligible for care leave to support their child, partner or parent with a life-threatening illness (Clarke, 2015). rights and the appropriate governmental support to advocate successfully for the needs and wishes of the childless. For example, in the absence of an advance directive dictating the wishes of the individual, in 30 US states, physicians cannot consult anyone about the care preferences of their incapacitated patients besides people related by blood, adoption or marriage (American Bar Association, 2014).

\section{Discussion}

We have examined how interdependence among lives in the family realm is influenced by two sets of societal forces: demographic conditions and national legislation. First, altered fertility patterns and the rise in co-longevity have improved opportunities for cross-generational interdependence. Due to gender differences in life expectancy and age at parenthood, many more mothers and daughters, compared to fathers and sons, share the experience of ageing and growing old together. Second, policies shape generational interdependence by defining rights and duties towards old and young in the family, and by reinforcing or lightening the reliance on older and younger family members.

Cross-generational ties in the family are a source of economic, cultural, and social capital. Given the increasing prevalence and duration of such ties, it becomes important not to forget the exceptions. Here, the bookend generations-the young and the oldare of special interest. Scholars and policy makers should be careful not to overlook statistical outliers: children with no or limited access to grandparents, and mature individuals who are generational solos, i.e., without any direct ascendant or descendant links. Such persons are generally ignored partly because much research on family ties in old age is anchored in samples of parents and children (Herlofson \& Hagestad, 2011).

In an increasingly "top-heavy" age structure, who are the children who are "vertically rich", and who are the "vertically deprived"? Several authors (e.g. EspingAndersen 2002; Heckman 2006; Sørensen 2005) have raised concerns about how children and young people with limited vertical ties (e.g. with single parents or no available grandparents) find ties that secure contact, support, and learning across age and generation lines. These authors argue that the availability or lack of intergenerational family relationships, especially with grandparents, is a major factor in the widening 
inequality among young people. Such concerns have also been raised in discussions of societal age segregation (Hagestad \& Uhlenberg, 2006) because it is hard to find arenas outside the family realm in which young and old can meet.

SHARE data show that $12 \%$ of the respondents (aged 50+) in Germany, Austria and Italy are solo individuals. In Italy, they even outnumber those belonging to structures of four and five generations (Kohli, Künemund, \& Lüdicke, 2006). Analysis of intergenerational family constellations based on data from the Generations and Gender Survey reveal that the share of generational solos among the 60-79 year olds varies from $5 \%$ in Bulgaria to $18 \%$ in Germany (Puur, Sakkeus, Põldma, \& Herm, 2011). It is worth noting that in some societies, generational solos encompass a considerable number of people who represent a challenge to health and social services (Wenger, 2009). Many are socially isolated, live in remote areas, and lack contacts who will serve as bridges to the care system.

As Northern Europeans, we take for granted that the provision of financial support and care to dependents is not only a private, but also a public issue. We have given empirical illustrations of the division of responsibilities between the state and families for childcare and eldercare. Research shows that public policy arrangements can enable autonomy between family generations, in such a way that "individual adults can uphold a socially acceptable standard of living, independently of family relationships, either through paid work or through the social security system" (Lister, 1994, p. 37). Autonomy is most likely when public provisions involve care services such as home help and daycare rather than payments for care. Care services better enable family members to remain gainfully employed, whereas cash benefits serve as an incentive to reduce working hours-particularly for women and for those with limited labour market prospects. Research also shows that targeted policies, such as the daddy quota, have improved gender equality by facilitating mothers' labour force participation, reducing work-life conflict, and encouraging fathers to become more involved in their children's lives.

In our considerations of the ways in which policies shape generational interdependence, we have not discussed the absence of policy, described as "non-policy" by Leisering (2004) and as "policy inaction" by Lloyd-Sherlock (2015). Saraceno (2010) introduced the concept of "familialism by default" to describe situations in which families provide all the care and financial support to dependent family members because there are no publicly provided alternatives. Here we draw attention to a striking contrast between the situation in Europe and that in the United States. Though it is conceivably the most individualized country in the world, the United States has high degrees of family interdependence. The latter is attributable to the lack of state mechanisms for risk reduction (cf. Leisering \& Leibfried, 1999). The less public support there is, the greater the risk of exploitation of unpaid family carers, potential harm to care recipients, and disparities between those who can afford to purchase care services and those who cannot (Lloyd-Sherlock, 2015; Saraceno, 2010).

\section{References}

Abendroth, A. K., Huffman, M. L., \& Treas, J. (2014). The parity penalty in life course perspective: Motherhood and occupational status in 13 European countries. American Sociological Review, 79(5): 993- 1014.

American Bar Association (2014). Default Surrogate Consent Statutes. http://www.americanbar.org/content/dam/ aba/administrative/law_aging/2014_default_surrogate_ consent_statutes.authcheckdam.pdf Accessed May 27, 2016

Anttonen, A., \& Sipilä, J. (1996). European social care services: Is it possible to identify models? Journal of European Social Policy, 6(2): 87-100.

Bengtson, V. L. (2001). Beyond the nuclear family: the increasing importance of multigenerational bonds. Journal of Marriage and the Family, 63(1): 1-16.

Bettio, F., \& Plantenga, J. (2004). Comparing care regimes in Europe. Feminist Econonomics, 10(1): 85-113.

Boll, C., Leppin, J., \& Reich, N. (2014). Paternal child- care and parental leave policies: Evidence from industrialized countries. Review of Economics of the Household, 12(1): 129-158.

Bonsang, E. (2009). Does informal care from children to their elderly parents substitute for formal care in Europe? Journal of Health Economics, 28(1): 143-54.

Bordone, V., Arpino, B., \& Aassve, A. (2016). Patterns of grandparental child care across Europe: The role of the policy context and working mothers' need. Ageing \& Society, First View. DOI: http://dx.doi.org/10.1017/ S0144686X1600009X

Brandt, M., Haberkern, K., Szydlik, M. (2009). Intergenerational help and care in Europe. European Sociological Review, 25(2): 585-601.

Brocas, A., Cailloux, A., \& Oget, V. (1990). Women and Social Security: Progress Towards Equality of Treatment. Geneva: International Labor Office.

Carling, J., Menjívar, C., \& Schmalzbauer, L. (2012). Central themes in the study of transnational parenthood, Journal of Ethnic and Migration Studies, 38(2): 191-217. 
Clarke, B. (2015). New Dutch laws in effect from July 1, 2015. http://www.iamexpat.nl/read-and-discuss/expat-page/ news/new-dutch-laws-from-july-1-2015 Accessed May 29, 2016.

Economist (2016, March 3). The best-and worst-places to be a working woman. http://www.economist.com/blogs/ graphicdetail/2016/03/daily-chart-0 Accessed May 26, 2016.

Elder, G. H., Jr. (1974). Children of the Great Depression: Social Change in Life Experience. Chicago: University of Chicago Press. xxiii plus $400 \mathrm{p}$.

Elder, G. H., Jr., Shanahan, M. J., \& Jennings, J. A. (2015). Human development in time and place. In: M. H. Bornstein \& T. Leventhal (Eds.), Handbook of child psychology and developmental science (Ecological settings and processes, Vol. 4), pp. 6-54. Hoboken: Wiley.

Esping-Andersen, G. (2002). A child-centred social investment strategy. In: G. Esping-Andersen, D. Gallie, A. Hemerijck, \& J. Myles (Eds.), Why we Need a New Welfare State, pp. 26-67. Oxford: Oxford University Press.

European Commission (2015). The 2015 Pension Adequacy Report: Current and Future Income Adequacy in Old Age in the EU. Volume I. Luxembourg: Publications Office of the European Union. 396 p.

Eydal, G. B., \& Rostgaard, T. (Eds.) (2015). Fatherhood in the Nordic Welfare States: Comparing Care Policies and Practice. Bristol: Policy Press. 352 p.

Gee, E. M. (1987). Historical changes in the family life course of Canadian men and women. In: V. Marshall, V. (Ed), Aging in Canada ( $2^{\text {nd }}$ ed.), pp. 265-287. Markham, Ontario: Fitzhenry and Whiteside.

Glick, P.C. (1947). The family cycle. American Sociological Review, 12(2): 164-174.

Hagestad, G. O. (1991). Trends and dilemmas in life course research: An international perspective. In Heinz, W. R. (Ed.), Theoretical Advances in Life Course Research, pp. 23-57. Winheim: Deutscher Studien Verlag.

Hagestad, G. O., \& Dykstra, P. A. (2016). Structuration of the life course: Some neglected aspects. In: M. J. Shanahan J. T. Mortimer, \& M. Kirkpatrick Johnson (Eds.), Handbook of the Life Course, Volume II, pp. 131-157. New York: Springer.

Hagestad, G.O. and Herlofson, K. (2012). Aldring [Ageing]. In: Frønes, I. and Kjølsrød, L. (eds.). Det norske samfunn. Oslo: Gyldendal akademisk: 414-434.

Hagestad, G. O., \& Uhlenberg, P. (2006). Should we be concerned about age segregation? Some theoretical and empirical explorations. Research on Aging, 28(6): 638-653.

Hagestad, G. O. \& Uhlenberg, P. (2007). The impact of demographic changes on relations between age groups and generations: a comparative perspective. In: K. W. Schaie \& P. Uhlenberg (Eds.), Social Structures: Demographic Changes and the Well-being of Older Persons, pp. 239-261. New York: Springer.

Heckman, J. J. (2006). Skill formation and the economics of investing in disadvantaged children. Science, 312(5782), 1900-1902.

Herlofson, K. \& Hagestad,G. (2011) Challenges in moving from macro to micro: Population and family structures in ageing societies. Demographic Research, 25: 337-370
Herlofson, K., \& Ugreninov, E. (2014). Er omsorgsfulle fedre omsorgsfulle sønner? Likestilling hjemme og hjelp til eldre foreldre [Are caring fathers caring sons? Gender equality at home and help to ageing parents], Tidsskrift for Samfunnsforskning, 55, 322-346.

Ivanova, K., \& Dykstra, P. (2015). Aging without children. Public Policy \& Aging Report, 25(3): 98-101. Special issue on Aging families and lagging policies (J. Angel \& R. Settersten, Eds.).

Javornik, J. (2014). Measuring state de-familialism: Contesting post-socialist exceptionalism. Journal of European Social Policy, 24(3): 240-257.

Kohli, M., Künemund, H., \& Lüdicke, J. (2006). Family structure, proximity and contact. In: A. Börsch-Supan, A. Brugiviani, H. Jürges, J. Mackenbach, J. Siegrist \& G. Weber (Eds): Health, Ageing and Retirement in Europe. First Results from the Survey of Health, Ageing and Retirement in Europe, pp. 164-170, 207-231. Mannheim: Mannheim Research Institute for the Economics of Aging.

Kotsadam, A., \& Finseraas, H. (2011). The state intervenes in the battle of the sexes: Causal effects of paternity leave. Social Science Research, 40(6) : 1611-1622.

Leisering, L. (2004). Government and the life course. In: J. T. Mortimer \& M. J. Shanahan (Eds.), Handbook of the Life Course, pp. 205-225. New York: Springer.

Leisering, L., \& Leibfried, S. (1999). Times of Poverty in Western Welfare States. Cambridge, UK: Cambridge University Press.

Leitner, S. (2003). Varieties of familialism: The caring function of the family in comparative perspective. European Societies, 5(4): 353-375.

Leopold, T., \& Skopek, J. (2015). The demography of grandparenthood: an international profile. Social Forces, 94(2): 801-832.

Lister, R. (1994). She has other duties: Women, citizenship and social security. In S. Baldwin \& J. Falkingham (Eds.), Social Security and Social Change: New Challenges to the Beveridge Model, pp. 31-44. London: Harvester Wheatsheaf.

Lohmann, H., \& Zagel, H. (2016). Family policy in comparative perspective: The conceptsand measurement of familization and defamilization. Journal of European Social Policy, 26(1): 48-65.

Lloyd-Sherlock, P. (2015). Barriers to linking research and policy: The case of long-term care in low and middle income countries. Population Horizons, 12(2): 62-67.

Marshall, V. W., \& Bengtson, V. L. (2011). Theoretical perspectives on the sociology of aging. In R. A. Settersten, Jr. \& J. L. Angel (Eds.), Handbook of Sociology and Aging, pp. 17-33. New York: Springer.

Mayer, K. U., \& Müller, W. (1986). The state and the structure of the life course. In A. B. Sorensen, F. Weinert, \& L. R. Sherrod (Eds.), Human Development and the Life Course, pp. 217-245. Hillsdale: Lawrence Erlbaum.

Moss, P. (Ed.) (2015). 11th International Review of Leave Policies and Related Research 2015. London: Institute of Education University of London. 350p. http://www.leavenetwork. org/fileadmin/Leavenetwork/Annual_reviews/2015_full_ review3_final_8july.pdf Accessed May 27, 2016. 
Multilinks (2011). Multilinks Database on Intergenerational Policy Indicators. Version 2.0, Multilinks Project and Wissenschaftszentrum Berlin für Sozialforschung (WZB), http://multilinks-database.wzb.eu.

Murphy, M. (2011). Long-term effects of the demographic transition on family and kinship networks in Britain. Population and Development Review, 377(S1): 55-80.

O'Connor, J. S. (1996). Citizenship, welfare state regimes and gender stratification. Current Sociology, 44(2): 48-77.

OECD (2015). Pensions at a Glance 2015: OECD and G20 Indicators. Paris: OECD Publishing. 375p.

Orloff, A. S. (1993). Gender and the social rights of citizenship: The comparative analysis of gender relations and welfare states, American Sociological Review, 58(3): 303-28.

Post, W., Van Imhoff, E., Dykstra, P. A., \& Van Poppel, F. (1997). Verwantschaps-netwerken in Nederland: Verleden, heden en toekomst [Kinship networks in the Netherlands: Past, present and future] (NIDI Report no. 51). Den Haag: NIDI. $117 \mathrm{p}$.

Population Reference Bureau. (2015). 2015 World Population Data Sheet. 23p. http://www.prb.org/pdf15/2015-worldpopulation-data-sheet_eng.pdf Accessed June 2, 2016

Puur, A., Sakkeus, L., Põldma, A., \& Herm, A. (2011). Intergenerational family constellations in contemporary Europe: Evidence from the Generations and Gender Survey. Demographic Research, 25: 135-172.

Ryder, N. (1965). The cohort as a concept in the study of social change. American Sociological Review, 30(6): 843-861.

Saraceno, C. (2010). Social inequalities in facing old-age dependency: A bi-generational perspective. Journal of European Social Policy, 20(1): 32-44.

Saraceno, C. (forthcoming). Family matters: An underestimated area of the constraints on the development of a European citizenship at the crossroad of civil laws and social policies. In A. K. Harris \& M. Vaduagna (Eds.), Shifting Notions of Citizenship: The Two “Wests”. New York: Columbia University Press.

Saraceno, C., \& Keck, W. (2008). The Institutional Framework of Intergenerational Family Obligations in Europe: A Conceptual and Methodological Overview. Deliverable 1.1 for the FP-7 funded project "How demographic changes shape intergenerational solidarity, well-being, and social integration: A multilinks framework". http://www. multilinks- project.eu/wp-content/uploads/2009/ 04/ Report_Saraceno_Keck_Nov081.pdf Accessed 26 May 2016.
Saraceno, C., \& Keck, W. (2010). Can we identify intergenerational policy regimes in Europe? European Societies, 12(5): 675-696.

Schmid, T., Brandt, M., \& Haberkern, K. (2012). Gendered support to older parents: Do welfare states matter? European Journal of Ageing, 9(1): 39-50.

Sørensen, A.-M. (2005). Family structure, gender roles and social inequality. In S. Svallfors (Ed.), Analyzing inequality. Life Chances and Social Mobility in Comparative Perspective, pp. 108-128). Palo Alto: Stanford University Press.

Uhlenberg, P. (1996). Mortality Decline in the Twentieth Century and Supply of Kin Over the Life Course, 36(5): 681-685.

Uhlenberg, P. (2004). Historical forces shaping grandparentgrandchild relationships: Demography and beyond. In: M. Silverstein \& K. W. Schaie (Eds.), Annual Review of Gerontology and Geriatrics (Vol. 24), pp. 77-97). New York: Springer.

Uhlenberg, P. (2009). Children in an aging society. Journal of Gerontology: Social Sciences, 64B(4): 489-496.

United Nations, Department of Economic and Social Affairs, Population Division (2015).

World Population Ageing 2015. (ST/ESA/SER.A/348). 149p. http://www.un.org/en/development/desa/population/ publications/pdf/ageing/WPA2015_Report.pdf Accessed June 2, 2016

Verdery, A.M. (2015) Links between demographic and kinship transitions. Population and Development Review, 41(3): 465-484

Viazzo, P. P. (2010). Family, kinship and welfare provision in Europe, past and present: Commonalities and divergences. Continuity and Change, 25(1): 137-159.

Wenger, G. C. (2009). Childlessness at the end of life: Evidence from rural Wales. Ageing \& Society, 29(8): 1243-1259.

Wheaton, F. V., \& Crimmins, E. M. (2016). Female disability disadvantage: a global perspective on sex differences in physical function and disability. Ageing \& Society, 36(6): 1136-1156.

Zagel, H., \& Lohmann, H. (2016). Family policy in comparative perspective: The conceptsand measurement of familization and defamilization. Journal of European Social Policy, 26(1): 48-65.

Zhou, Y. R. (2012). Space, time, and self: Rethinking aging in the contexts of immigration and transnationalism. Journal of Aging Studies, 26(3): 232-242. 